\title{
Granule Cell Raphes and Parasagittal Domains of Purkinje Cells: Complementary Patterns in the Developing Chick Cerebellum
}

\author{
John C. Lin and Constance L. Cepko \\ Genetics Department, Howard Hughes Medical Institute, Harvard Medical School, Boston, Massachusetts 02115
}

The extensive migration of granule cells and the parasagittal organization of Purkinje cells are two prominent features of cerebellar development. Using granule cell markers, we observed that the inward migration of a subset of granule cells occurs in streams that appear to be restricted to specific areas in the developing chick cerebellum. These streams are organized into a stereotypical series of parasagittal linear arrays, similar to the "granule cell raphes" described previously by Feirabend (1990). Similar raphes were found in the developing cerebellum of other avian species but not in the mouse cerebellum. During the period when granule cell raphes are apparent, Purkinje cells appear to be segregated into discrete parasagittal domains, interrupted by Purkinje cell-poor areas that correspond to the granule cell raphes. Purkinje cells in each domain exhibit a domain-specific expression profile of genes, including Bmp-7, EphA5/Cek-7, EphA4/Cek-8, and several chick homologs of Drosophila segmentation genes. From embryonic day 12 (E12) to E15, most of these genes gradually cease to be expressed differentially in parasagittal stripes, concurrent with the disappearance of the granule cell raphes by E15-E16. The spatial and temporal correlations of granule cell raphes and Purkinje cell parasagittal domains suggest a novel interaction between these two cell types and a potentially critical period of parasagittal patterning of the chick cerebellum.

Key words: granule cells; migration; Purkinje cells; patterning; chick embryo; cerebellum
The cerebellum is a highly conserved structure of the vertebrate CNS (for review, see Llinus and Hillman, 1969). Well known for its role in motor coordination, the cerebellum is highly interconnected to many areas of the CNS. Our appreciation of the functions of these connections, although still rather primitive, is growing, especially with regard to a role in motor learning (Raymond et al., 1996). The key cellular elements of the cerebellar circuitry include granule cells, the primary interneurons of the cerebellum, and Purkinje cells, an archetype of projection neurons. Both cell types have properties that make them amenable to experimental investigations and thus have been the focus of many studies of cerebellar development (for review, see Hatten and Heintz, 1995).

Granule cells have an unusual developmental history. Although almost all CNS progenitor pools line the interior (i.e., ventricular) surface of the brain, granule cells are derived exclusively from a progenitor pool residing on the external surface of the cerebellum (Ramon y Cajal, 1911; Gao and Hatten, 1994; Zhang and Goldman, 1996). This external progenitor pool, or external granule layer (EGL), originates from the caudal region of the cerebellar anlage, the rhombic lip. EGL cells migrate rostrally from the rhombic lip to cover the dorsal surface of the cerebellar anlage. EGL cells proliferate in the superficial layer of the EGL and give rise to postmitotic cells that migrate trans-

Received July 15, 1998; revised Aug. 27, 1998; accepted Aug. 28, 1998.

This work was supported by the Howard Hughes Medical Institute. We thank R. L. Johnson for bringing to our attention the Shh expression in the chick cerebellum. We thank H.-J. Cheng, D. K. Darnell, J. G. Flanagan, J. A. Golden, R. L. Johnson, V. Marigo, E. Pasquale, R. D. Riddle, C. J. Tabin, and V. I. Teichberg for probes. We also would like to thank members of the Cepko lab for critical reading of this manuscript.

Correspondence should be addressed to Dr. Constance Cepko, Genetics Department, Howard Hughes Medical Institute, Harvard Medical School, 200 Longwood Avenue, Boston, MA 02115.

Copyright (C) 1998 Society for Neuroscience $\quad 0270-6474 / 98 / 189342-12 \$ 05.00 / 0$ versely within the deeper layers of the EGL before they eventually move inward to the inner granule layer (IGL) (Hallonet et al., 1990; Ryder and Cepko, 1994). The interaction between granule cells and Bergmann glial fibers is important for this final inward migration of granule cells (Rakic, 1971; for review, see Hatten, 1993).

Purkinje cells are derived from the more typically situated progenitors in the ventricular zone (VZ) of the fourth ventricle. These neurons migrate, along with several other cell types, outward from the VZ into the cerebellar cortex (Hallonet et al., 1990; Otero et al., 1993). In the adult cerebellum, Purkinje cells are evenly distributed in a monolayer that is organized into discrete parasagittal domains, defined by their patterns of connectivity and gene expression (for review, see Voogd, 1969; Hawkes et al., 1992; Wassef et al., 1992; Hawkes and Mascher, 1994). Millen et al. (1995) showed that a number of homologs of Drosophila segment polarity genes (En-1, En-2, Pax-2, and $W n t-7 b)$ were transiently expressed in alternating parasagittal domains in the developing mouse cerebellum and that these patterns were altered in En-2 knock-out mice. It was thus suggested that these genes might be involved in the parasagittal patterning of the cerebellar cortex.

Here we report a novel relationship between granule cells and Purkinje cells in the developing chick cerebellum. Using molecular markers, we found that subsets of granule cells follow pathways arranged in parasagittal linear arrays during the early phase of inward migration. We also identified several novel markers for parasagittal domains of chick Purkinje cells and used these markers to demonstrate that the Purkinje cell domains were often bordered by the inwardly migrating arrays of granule cells. These observations suggest that granule cell migration and Purkinje cell patterning are highly coordinated in chick cerebellar develop- 
ment. In addition, the same set of homologs of Drosophila segmentation genes reported to be patterned in the developing murine cerebellum (Millen et al., 1995) exhibits significantly different patterns of expression in the developing chick cerebellum, suggesting a potential role in the evolution of cerebellar patterning.

\section{MATERIALS AND METHODS}

Fertilized White Leghorn eggs were purchased from SPAFAS (Norwich, $\mathrm{CT}$ ). Fertilized eggs of ducks and of Cortunix and Bobwhite quails were purchased from Metzer farm (Gonzales, CA).

PCR cloning of chick $\mathrm{Zic}$ gene probes. DNA fragments of the chick homologs of the mammalian Zic gene family were generated by RT-PCR using the total RNA prepared from embryonic day 8 (E8) chick brain tissue and the following pair of degenerate primers: a $5^{\prime}$ primer encoding the peptide sequence MHELVTH and a $3^{\prime}$ primer encoding the peptide sequence KHMKVH. Both of these peptide sequences are completely conserved in all mouse Zic genes and in the Drosophila pair-rule gene odd-paired (Aruga et al., 1996). Two related but distinct clones of $\sim 400$ bp were isolated and sequenced following standard protocols. Each clone predicted an amino acid sequence highly homologous to the multiple zinc finger domains of the mouse $Z i c$ genes (see Fig. 1A). Using a comparison with the published mouse $Z i c$ gene sequences, we tentatively identified these clones as chick Zic-1 and Zic-3.

In situ hybridization. The chick probes for in situ hybridization were as follows: chKBP (Gregor et al., 1989); Shh (Riddle et al., 1993); Gli-2/4 [originally the chick Gli-3 of Marigo et al. (1996); now reassigned as the chick Gli-2/4 by Borycki et al. (1998)]; Bmp-7 (Oh et al., 1996); Pax-2 and Pax-6 (gifts of J. Golden); EphA5/Cek-7 (Sajjadi and Pasquale, 1993); EphA4/Cek-8 (Cheng et al., 1995); En-1 (Noramly et al., 1996); and En-2 (Darnell et al., 1992). Whole-mount in situ hybridization procedures were performed essentially according to the method of Riddle et al. (1993) with the following modification. Dissected E7-E12 chick brains were treated with a high concentration of proteinase $\mathrm{K}(20-40 \mu \mathrm{g} / \mathrm{ml})$ for 15-25 min at room temperature to enhance probe penetration.

In situ hybridization of cerebellar sections was performed on $10 \mu \mathrm{m}$ paraffin sections of chick cerebella. Briefly, the paraffin sections were processed at room temperature sequentially for paraffin removal, rehydration, and incubation with proteinase $\mathrm{K}(10 \mu \mathrm{g} / \mathrm{ml})$ for $5-10 \mathrm{~min}, 4 \%$ paraformaldehyde for $30 \mathrm{~min}$, and glycine $(7.5 \mathrm{mg} / \mathrm{ml})$. Then each slide was hybridized with a digoxygenin-labeled riboprobe at $\sim 1 \mathrm{ng} / \mathrm{ml}$ in 70 $\mu \mathrm{l}$ of hybridization solution ( $40 \%$ formamide, $5 \times$ SSC, $1 \times$ Denhardt's solution, $100 \mu \mathrm{g} / \mathrm{ml}$ salmon sperm DNA, and $100 \mu \mathrm{g} / \mathrm{ml}$ tRNA) at $70^{\circ} \mathrm{C}$ for 12-16 hr. After hybridization, the sections were washed successively with washing solution $(20 \%$ formamide and $0.5 \times \mathrm{SCC})$ at $65^{\circ} \mathrm{C}$ for 40 min, NTE $(0.5 \mathrm{M} \mathrm{NaCl}, 10 \mathrm{~mm}$ Tris-Cl, $\mathrm{pH} 7.5$, and $5 \mathrm{~mm}$ EDTA $)$ at $37^{\circ} \mathrm{C}$ for $15 \mathrm{~min}$, RNase A $(10 \mu \mathrm{g} / \mathrm{ml} \mathrm{NTE})$ at $37^{\circ} \mathrm{C}$ for $30 \mathrm{~min}, \mathrm{NTE}$ at $37^{\circ} \mathrm{C}$ for $15 \mathrm{~min}$, washing solution at $65^{\circ} \mathrm{C}$ for $30 \mathrm{~min}$, and $2 \times \mathrm{SCC}$ at room temperature for $30 \mathrm{~min}$. For detection, the slides were first incubated with $1 \%$ blocking solution (Boehringer Mannheim, Indianapolis, IN) for $10 \mathrm{~min}$, with alkaline phosphatase (AP)-conjugated anti-digoxygenin antibody (Boehringer Mannheim) at room temperature for $3 \mathrm{hr}$, and then with BM purple color substrate (Boehringer Mannheim). The AP color reaction were stopped after $24-48 \mathrm{hr}$ when satisfactory intensity of signal over background was achieved.

Immunohistochemistry. The primary antibodies were used at the following dilutions: anti-calbindin (1:1000; Sigma, St. Louis, MO); H5, a mouse anti-vimentin (1:100; Developmental Studies Hybridoma Bank); and Pax6 antibody (1:20; Developmental Studies Hybridoma Bank). Immunohistochemistry was performed on $20-30 \mu$ m cryosections using the Vectastain Elite kit (Vector Laboratories, Burlingame, CA), except that the Texas Red-conjugated donkey anti-mouse secondary antibody (Jackson Laboratories) was used for anti-vimentin staining. In some experiments, Pax6 antibody staining was performed after the completion of the in situ hybridization procedure of a given riboprobe on the same sections. It was noted, however, that such a double-labeling protocol did not work for calbindin antibody.

5'-Bromodeoxyuridine labeling and detection. The procedure of 5'bromodeoxyuridine (BrdU) labeling and immunohistochemical detection was essentially the same as described (Ryder and Cepko, 1994) with the following modifications; $0.2 \mathrm{ml}$ of $\operatorname{BrdU}(2 \mathrm{mg} / \mathrm{ml})$ in PBS was injected into the yolk of each egg at E10.5-E13.5. The eggs were returned to the incubator for $1-1.5 \mathrm{hr}$ before harvesting. The cerebella of BrdUlabeled embryos were dissected and fixed in $4 \%$ paraformaldehyde at $4{ }^{\circ} \mathrm{C}$ for $6-8 \mathrm{hr}$. Immunohistochemical detection with a monoclonal antibody for BrdU (Amersham, Arlington Heights, IL) was according to the manufacturer's instructions.

Cresyl violet staining. Ten micrometer coronal paraffin sections of chick cerebellum were prepared, defatted in $70 \%$ ethanol for $3 \mathrm{hr}$, and rehydrated. The sections were stained with $0.1 \%$ cresyl violet, $\mathrm{pH} 3.5$, at room temperature for $\sim 15 \mathrm{~min}$, dehydrated, and then put in differentiating solution ( 1 drop of glacial acetic acid per $100 \mathrm{ml}$ of $95 \%$ ethanol) for a variable period of time until optimal contrast between cells and background was obtained. The sections were then put through $100 \%$ ethanol and xylenes and mounted with nonwater-soluble mounting medium (Permount).

\section{RESULTS}

\section{Early inward migration of chick cerebellar granule cells is organized in parasagittal arrays}

To study the migration of granule cells in the developing chick cerebellum, we cloned DNA fragments of the chick homologs of the mouse Zic genes (Zic-1 and Zic-3; see Materials and Methods and Fig. $1 A$ ), which had been shown to be expressed in granule cells in the mouse EGL and IGL (Aruga et al., 1994, 1996). Under stringent conditions of in situ hybridization, the chick Zic-1 and Zic-3 were found to be expressed in distinct manners during development (Fig. 1B,C), but the patterns of their expression in the cerebellum were indistinguishable. We will focus on Zic-1 in this report, but all of the essential features of Zic-1 expression in the developing chick cerebellum were also observed for Zic-3.

Examination of Zic-1 RNA expression by in situ hybridization revealed that, in addition to the transient expression in the cerebellar VZ, this gene is expressed in granule cells in the chick cerebellar cortex (Fig. 2). Zic-1 RNA could be detected in the EGL and the IGL (Fig. 2D,E). Moreover, it was highly expressed in a set of linear arrays perpendicular to the transverse folia (Fig. $2 B$ ). The pattern of linear arrays was observed from E8 (Fig. $2 A$ ) to E12.5 and was essentially invariant for cerebella of each age ( $>20$ cerebella examined for each embryonic day). On coronal sections of the cerebellum, the Zic-positive $\left(\right.$ Zic- $\left.1^{+}\right)$linear arrays consisted of a high concentration of cells connecting the EGL and the IGL, as visualized by the nuclear dye 4,6-diamidino-2phenylindole (DAPI) (Figs. 2E, 3). These linear arrays of Zic- $1^{+}$ cells appeared to be granule cells during their inward migration from the EGL to the IGL. In between the $\mathrm{Zic}-1^{+}$arrays were also some scattered $\mathrm{Zic}^{+}{ }^{+}$cells (Fig. 2E), indicating that inward migration of granule cells did not occur exclusively within the linear arrays. We noted that this pattern of linear arrays was similar to that reported by Feirabend (1990) (compare Fig. 2B with $F$ ). Feirabend proposed that there was a parasagittal pattern of granule cell migration, which he termed "granule cell raphes," during the early phase of chick cerebellar development (Feirabend, 1990) (see Discussion).

To confirm that the highly organized arrays of $\mathrm{Zic}-1^{+}$and Zic- $3^{+}$cells between the EGL and IGL are granule cells, we examined the expression of another granule cell marker, Pax-6 (Stoykova and Gruss, 1994). Pax-6 showed an RNA expression pattern similar to that of Zic-1 and Zic-3 (Figs. 2C, 3C), and the Pax-6 antibody also stained the granule cell raphes (Fig. 3D,F). In addition, we found that $P a x-2$ is expressed only in a posterior subset of granule cell raphes (Fig. 2G), even though Pax-2 was not known previously as a granule cell marker. When labeled with BrdU, these dense cellular arrays bearing several granule cell markers were found to contain relatively few mitotic cells (Fig. $3 E-G)$. Together these findings support the notion that a subset of postmitotic granule cells follow specific parasagittal pathways during their inward migration in the developing chick cerebellum. 


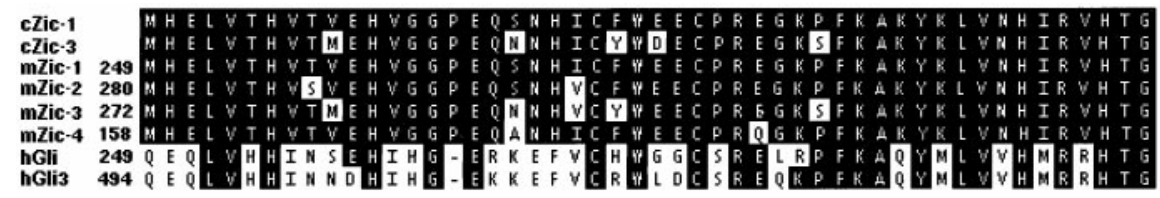

Figure 1. Cloning and embryonic expression of chick $Z i c$ genes. $A$, Sequence alignment of the chick Zic-1 (cZic-1) and Zic-3 (cZic-3) DNA fragments with the homologous zinc finger region of the murine Zic (mZic) genes (Aruga et al., 1996) and the human $G l i(h G l i)$ genes. B, C, In situ hybridization of E4.5 chick embryos using the chick Zic-1 $(B)$ and Zic-3 $(C)$ probes. Expression was seen in overlapping and yet distinct patterns. Both genes were expressed in the dorsal neural tube and the developing somites, but only Zic-3 was expressed in the developing limb at this time. The area shaded in black in $A$ represents sequences identical to the mouse Zic-1. Hyphens indicate gaps in the sequences.
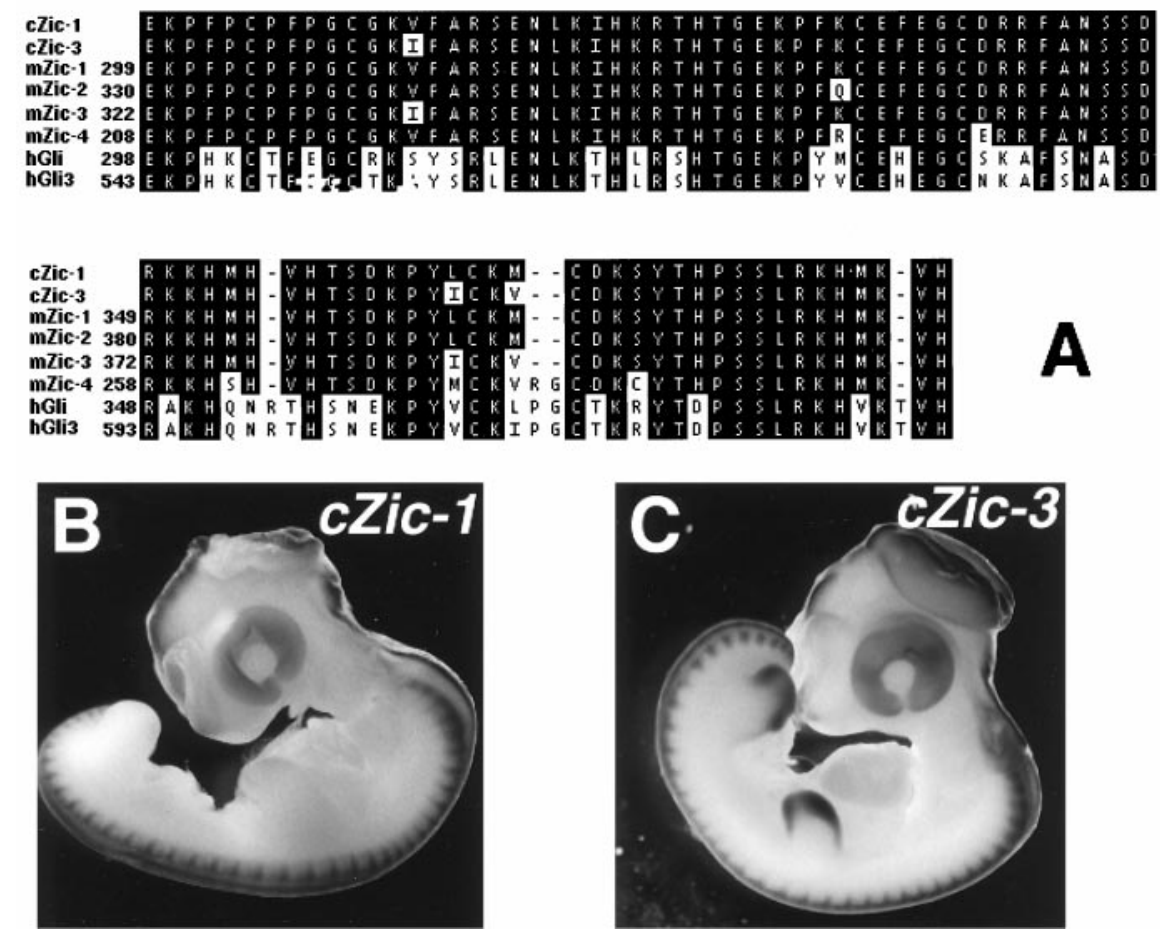

\section{Granule cell raphes are a conserved feature of avian cerebellar development}

We next asked whether the granule cell raphes were peculiar to the chick cerebellum, or whether they might be a more general feature of cerebellar development. They have not been reported to occur in any species other than chick. We thus looked for evidence of granule cell raphes first in other avian species. After DAPI nuclear staining, parasagittal arrays of high cell density extending from the EGL to the IGL were also visible in the developing duck and quail cerebellum (Fig. 4). The dense cellular arrays in adjacent folia tended to be in register with each other and are most likely the granule cell raphes in the duck and the quail cerebellum.

We also searched for the potential equivalent of granule cell raphes in the developing mouse cerebellum. However, we did not observe any consistent set of parasagittal arrays of migrating granule cells connecting the EGL and the IGL by (1) cresyl violet staining, (2) DAPI staining, and (3) in situ hybridization with the mouse Zic-1 probe in the mouse cerebellum at E17.5, postnatal day 1 (P1), and P4 (data not shown). These negative results are consistent with the lack of report of granule cell raphes in the comprehensive histological analysis of the developing rat cerebellum by Altman and Bayer (1997).

\section{Granule cell raphes do not correlate with the localization of Bergmann glia}

Bergmann glial fibers have long been recognized to be important in guiding the inward migration of granule cells (Rakic, 1971;
Zheng et al., 1996). One hypothesis to explain the observed pattern of granule cell raphes was that Bergmann glial fibers might be predominantly localized to specific areas during the early period of granule cell inward migration. In the chick cerebellum at E12, however, vimentin ${ }^{+}$Bergmann glial fibers were found to be distributed uniformly across the entire cerebellum (Fig. 5A) (Roeling and Feirabend, 1988). The spatial distribution of Bergmann glial fibers alone thus cannot account for the pattern of granule cell raphes.

An alternative hypothesis to explain the granule cell raphes was that specific Bergmann glial fibers might have certain unique properties such that these fibers could better support granule cell migration. This hypothesis predicted that a certain pattern(s) of glial gene expression might overlap with the granule cell raphes. To begin to explore this possibility, we examined the developmental expression of a chick kainate binding protein (chKBP), one of the best-characterized chick Bergmann glia-specific markers to date (Somogyi et al., 1990). It was possible that $\operatorname{chKBP}$ might, for example, mark particular Bergmann glial cells that had matured in advance of the majority of their neighbors. The onset of $\operatorname{ch} K B P$ RNA expression was found to be heterogeneous across the cerebellum at E10-E12 (Fig. 5C,D). Importantly, the areas with the earliest $c h K B P$ expression did not correspond to the parasagittal granule cell raphes (compare Fig. $5 B$ with $D$ ). Although this result failed to correlate a $\operatorname{ch} K B P$ expression pattern with granule cell raphes, it remains possible that novel glial gene expression patterns will be discovered in the future that correspond to the pattern of granule cell raphes. 

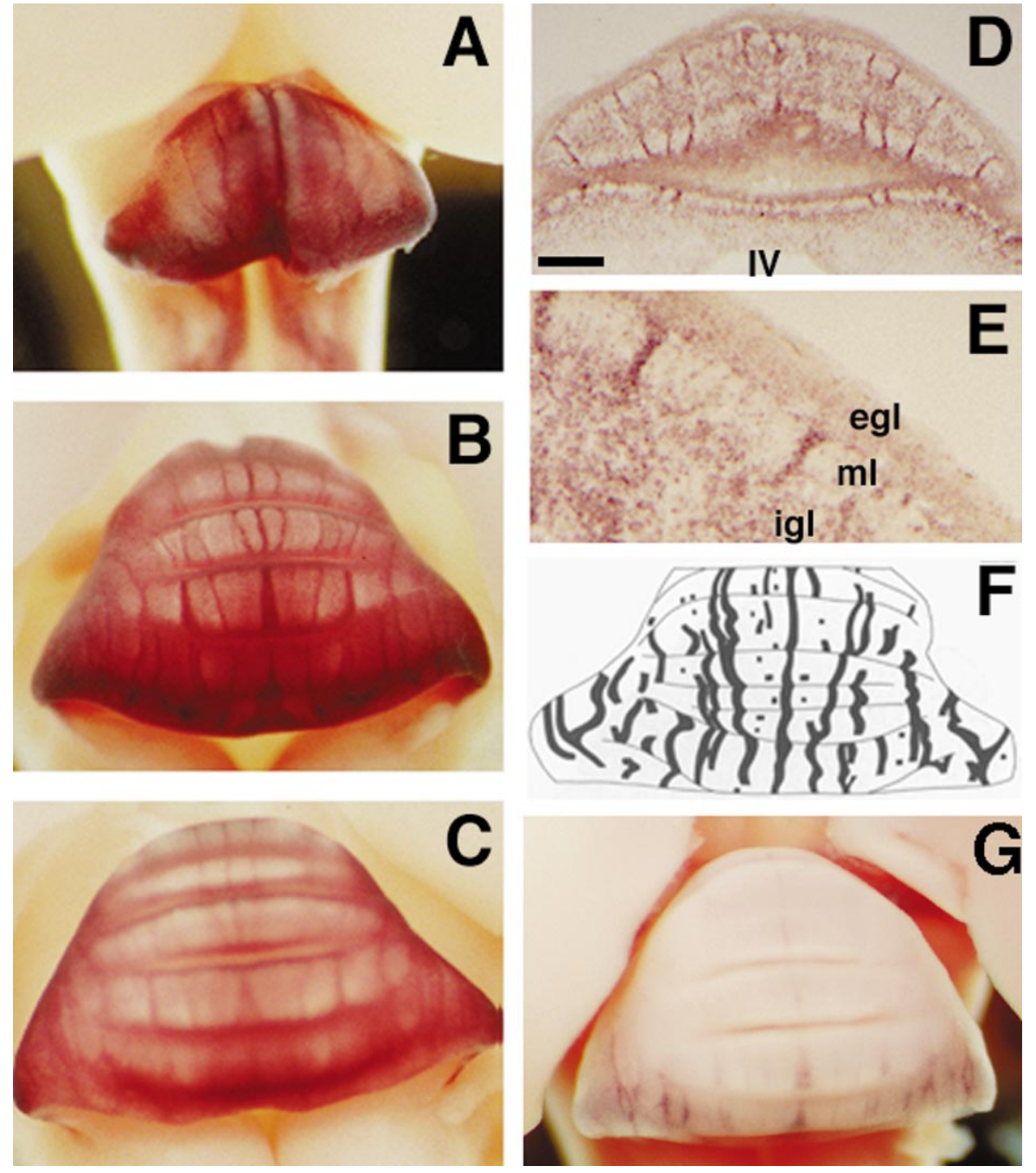

Figure 2. Expression of granule cell-specific markers in the developing chick cerebellum reveals parasagittal arrays of granule cells during the early period of inward migration. Dorsal views of E9 $(A)$ and E11 $(B, C, G)$ chick cerebellum hybridized with the Zic-1 $(A, B)$, the Pax-6 probe $(C)$, or the Pax -2 probe $(G)$, and coronal sections of an E13 chick cerebellum hybridized with the Zic-1 probe $(D, E)$ are shown. Anterior is at the top in $A-C, F$, and $G$. Dorsal is at the top in $D$ and $E$. $A-C$, Linear arrays running perpendicular to the transverse folia were detected by the granule cell-specific markers Zic-1 and Pax-6. D, E, Zic-1 expression was detected in granule cells in the external granule cell layer $(e g l)$, the internal granule cell layer $(i g l)$, the linear arrays spanning across the molecular layer $(m l)$, and some scattered cells in the $m l$. $F$, The original three-dimensional reconstruction of granule cell raphes by Feirabend (adopted from Feirabend, 1990) shows a global pattern similar to the expression pattern of Zic-1 and Pax-6. G, Pax-2 is expressed most strongly in the posterior subset of granule cell raphes. Scale bars: $A-C, G, 425 \mu \mathrm{m} ; D$, $400 \mu \mathrm{m} ; E, 100 \mu \mathrm{m}$.

\section{Granule cell raphes correspond to Purkinje cell-poor gaps}

Because there was no apparent correlation between the granule cell raphes and the known markers for Bergmann glia, we examined other cerebellar cells in relation to granule cell raphes. To detect Purkinje cells, which differentiate earlier than granule cells, we used an antibody against calbindin (CaBP). CaBP expression could be detected specifically in Purkinje cells of the chick cerebellum from E12 onward (Fig. 6; data not shown). Purkinje cells of certain regions began to express $\mathrm{CaBP}$ earlier than did those of other regions. Furthermore, some areas of the Purkinje cell layer remained $\mathrm{CaBP}$-negative $\left(\mathrm{CaBP}^{-}\right)$as late as E15-E16 (data not shown). Several features of the $\mathrm{CaBP}^{-}$gaps were noted. (1) A thicker and/or inwardly curved layer of $\mathrm{CaBP}^{+}$ cells was sometimes found adjacent to these gaps at E12.5 (Fig. $6 A, B),(2)$ each $\mathrm{CaBP}^{-}$gap generally coincided with a Zic-1/Zic$3 / \mathrm{Pax}^{-6^{+}}$granule cell raphe (Fig. $6 C, D$ ), and (3) the width of each $\mathrm{CaBP}^{-}$gap correlated with that of the corresponding granule cell raphe (Fig. 6A,C). These features suggested that the granule cell raphes corresponded to the $\mathrm{CaBP}^{-}$gaps in the Purkinje cell layer and that the $\mathrm{CaBP}^{-}$gaps may contain very few or no Purkinje cells. To exclude the possibility that there might still be $\mathrm{CaBP}^{-}$Purkinje cells inside the areas of granule cell raphes, we stained all cell bodies with cresyl violet (Fig. $6 E, F$ ). Interestingly, there was a cell-poor zone (Fig. $6 F$, black arrow- heads) adjacent to each granule cell raphe (Fig. $6 F$, white arrows), and the cell-poor zone was usually lateral to the granule cell raphe. Taken together, these observations support the notion that the continuity of the Purkinje cell layer is interrupted by the granule cell raphes.

\section{Granule cell raphes often correspond to the boundaries between Purkinje cell domains with distinct gene expression profiles}

The alignment of granule cell raphes with gaps in the Purkinje cell layer raised the question of whether the parasagittal Purkinje cell domains defined by granule cell raphes were of any functional significance. To investigate this possibility, we needed molecular markers that could distinguish parasagittal domains of the developing cerebellar cortex. Relatively few such markers had been reported in the chick, compared with those available in the mammalian cerebellum (e.g., Hawkes and Mascher, 1994).

Screening several previously cloned genes for expression by whole-mount in situ hybridization led to the identification of genes that were transiently expressed in parasagittal stripes in the developing chick cerebellum, including Bmp-7, EphA5/Cek-7, EphA4/Cek-8, En-1,En-2, Gli-2/4, and Shh (see Figs. 7-9; data not shown). Many of these genes were expressed in the cerebellum as early as E7-E8 (data not shown). From E8 to E12, these genes were expressed in parasagittal stripes in the presumptive Purkinje 

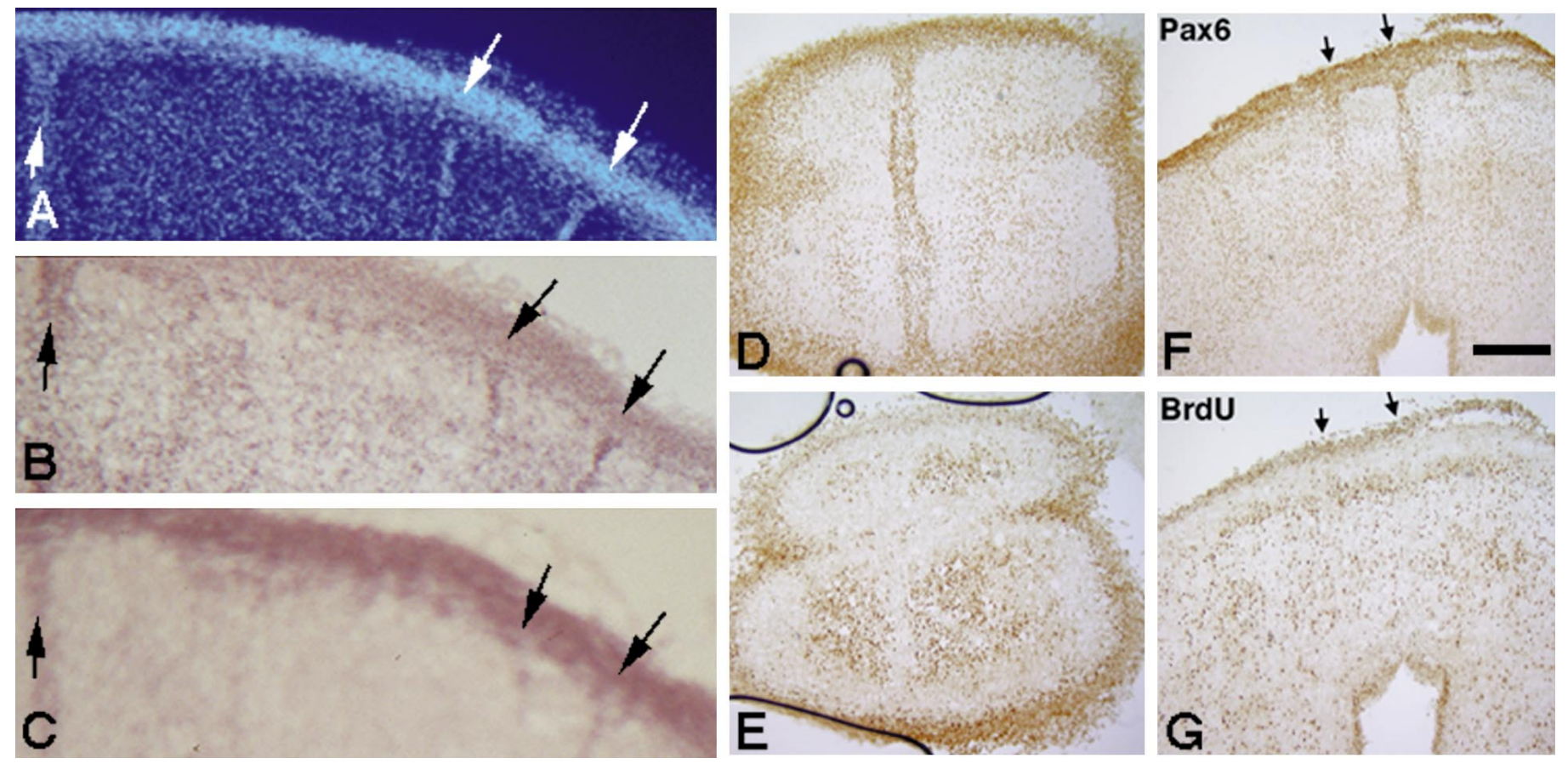

Figure 3. Characterization of the inward migratory arrays of granule cells. Coronal sections of the chick cerebellum, all with dorsal at the top, are shown. $A-C$, The correspondence of DAPI staining and Zic-1 and Pax-6 expression (arrows) in the E11 chick cerebellum is indicated. DAPI nuclear staining is shown in blue $(A)$, and in situ hybridization for Zic-1 $(B)$ or Pax-6 $(C)$ appears as purple. $D-G$, Granule cell arrays are postmitotic. Adjacent coronal sections are shown of an E11.5 chick cerebellum $1 \mathrm{hr}$ after BrdU injection at the rostral level $(D, E)$ and the caudal level $(F, G)$. Pax-6 $(D, F)$ and BrdU $(E, G)$ antibody staining are shown as brown nuclei. The superficial layer of the EGL contained many BrdU ${ }^{+}$cells, whereas the deeper layer of the EGL and the granule cell arrays (arrows) contained relatively few $\mathrm{BrdU}^{+}$cells, suggesting they are postmitotic. $\mathrm{The} \mathrm{BrdU}^{+}$cells scattered underneath the EGL most likely represent the glial cell precursors. Scale bars: $A-C, 100 \mu \mathrm{m} ; D-G, 200 \mu \mathrm{m}$.

cell layer (Figs. 7, 8). By E13-E14, when CaBP expression allowed for the identification of Purkinje cells, these genes were clearly expressed in the Purkinje cell layer in addition to other site(s) of expression (Fig. 7; data not shown). Importantly, Bmp-7, EphA5/Cek-7, EphA4/Cek-8, and Shh were not expressed in the $\mathrm{CaBP}^{-}$gaps of the Purkinje cell layer or in the $\mathrm{Zic}-1^{+}$granule cell raphes (Fig. 7, arrows), re-enforcing the idea that granule cell raphes correspond to the Purkinje cell-poor gaps of the developing Purkinje cell layer.

Each of these genes was characterized by a specific spatial and temporal profile of expression within the parasagittal domains of Purkinje cells. The level of mRNA expression varied consistently among individual parasagittal domains for a given gene from E8 to E12 (see Fig. $7 G-I$ for $E p h A 5 / C e k-7$; see Fig. $8 A 1, B 1, C 1$, for Bmp-7, En-1, and Gli-2/4, respectively; data not shown). The global expression patterns of these genes examined on wholemount preparations (Fig. $8 A-I$ ) confirmed that subsets of Purkinje cells with different levels of a given transcript tended to segregate into parasagittal domains and that each domain with a distinct gene expression profile was often bordered by the granule cell raphes. For example, in folium IXa $+\mathrm{b}$ at E11.5, a higher level of $B m p-7$ RNA was detected in domain $\mathrm{P} 3$ relative to that in $\mathrm{P} 2$ (Fig. $8 A 1, A, E$ ); a higher level of EphA5/Cek-7 mRNA was detected in domain $\mathrm{P} 2$ relative to that in $\mathrm{P} 1$ or $\mathrm{P} 3$ (Fig. $8 G, E$; see also Fig. $7 H$ ); and a much higher level of EphA4/Cek8 RNA was detected in domain $\mathrm{P} 4$ relative to that in the neighboring region of P3 (Fig. 8H,E). There was one parasagittal domain with high expression of En-1 near the midline in each hemicerebellum, which seemed to coincide with domain P1, and anther domain of higher expression was in the medial portion of P3 (Fig. 8B1,B,E). Similarly, there was one parasagittal domain of Gli-2/4 expression in each hemicerebellum, which generally ran within domain P3 (Fig. 8C1,C,E). These data together suggest that the parasagittal Purkinje cell domains divided by granule cell raphes are often domains of differential gene expression as well.

We noted, however, that certain domains defined by granule cell raphes did not correspond to any boundary of differential gene expression identified to date, including the numerous narrow domains lateral to P4 (Fig. 8). As our screen was by no means comprehensive, it is possible that additional differential expression patterns will be discovered that can be correlated with these lateral domains. Moreover, both the high level of EphA5/Cek-7 expression in domain $\mathrm{P} 2$ and that of Gli2/4 expression in domain P3 stopped abruptly at folium IXa+b (Fig. 8C,G). Thus, each parasagittal domain defined by granule cell raphes seemed to be further subdivided into smaller units.

\section{Granule cell raphes disappear by E15-E16}

The granule cell raphes were present only transiently during chick cerebellar development. Using an anti-Pax6 antibody to label granule cells and an EphA5/Cek-7 riboprobe to label Purkinje cells simultaneously, we observed the granule cell raphes and the Purkinje cell gaps at E12 and E13.5 (Fig. 9A-D, arrows). Although a few Purkinje cell gaps remained filled with granule cells at E15-E16 (Fig. 9F, arrowhead), there were no distinct arrays of granule cells connecting the EGL and the IGL by this time of development. Other granule cell markers (Zic-1 and Zic-3) also showed this developmental profile within the granule cell raphes (data not shown). Furthermore, the level of EphA5/Cek-7 expression in the parasagittal Purkinje domains evolved from highly differential at E11 (e.g., see Figs. $7 H, 8 G$ ) to barely distinguishable at E12 (Fig. 9A,B) and eventually became uniform at E15.5 

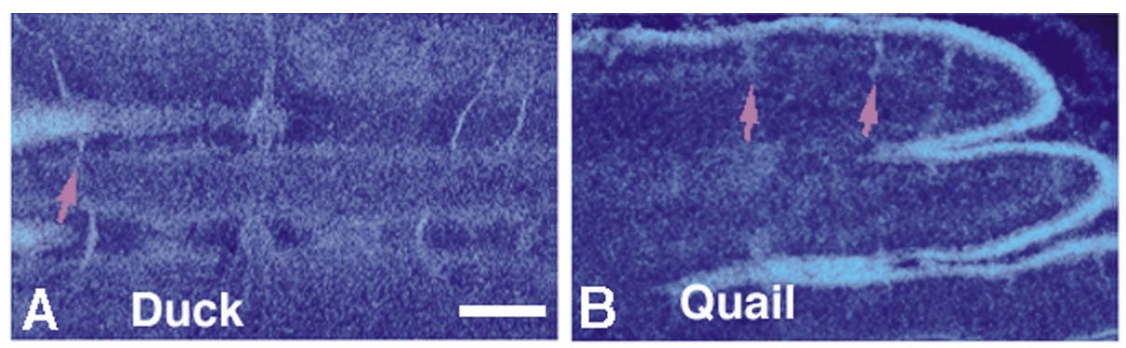

\section{Figure 4.}

\section{Figure 5.}
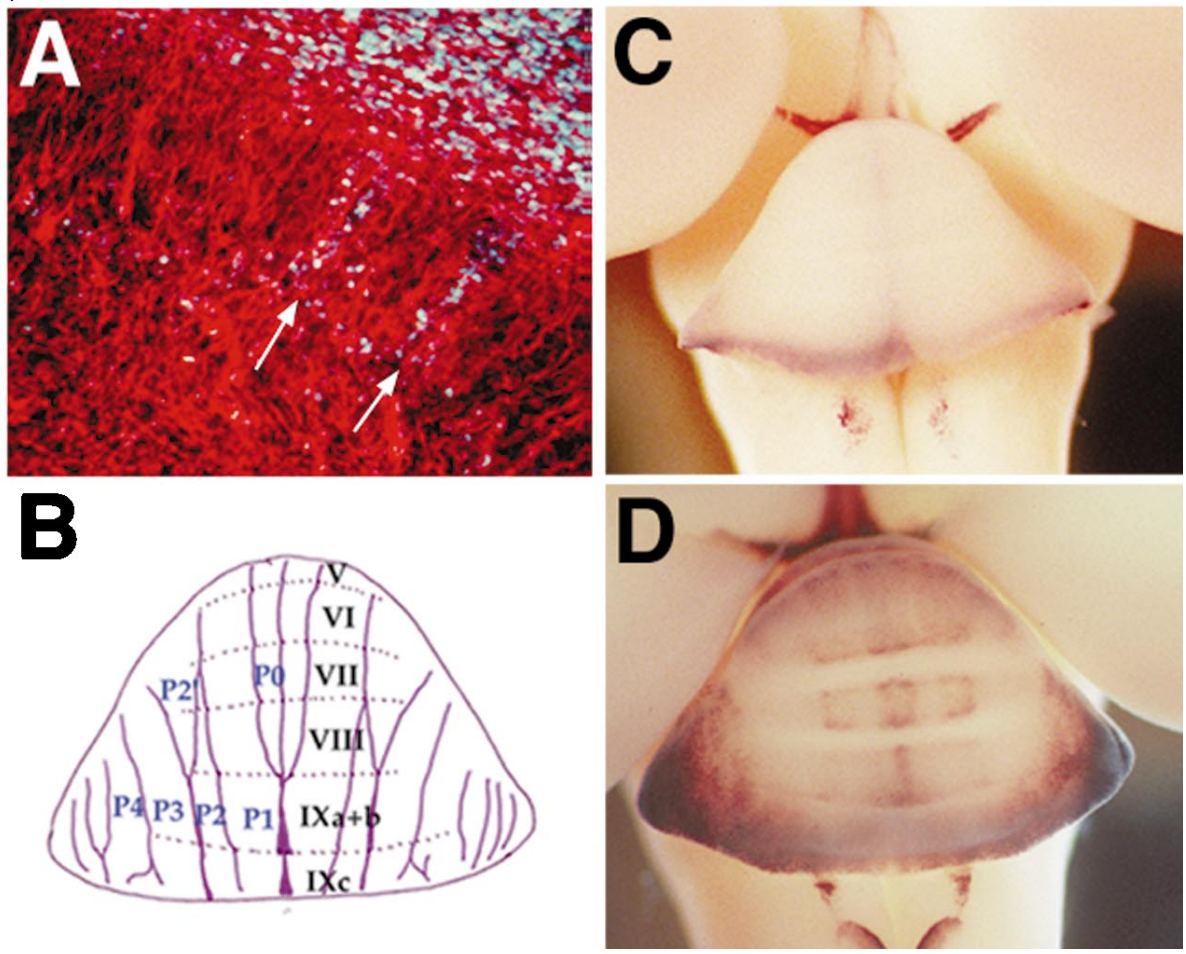

Figure 4. Granule cell raphes are present in the developing cerebellum of duck and quail. Coronal sections of E15 duck $(A)$ and E14 quail $(B)$ cerebellum are shown. DAPI nulear staining is shown in blue. Arrows indicate the parasagittal arrays of DAPI-labeled cells, most likely the granule cell raphes. Scale bar, $200 \mu \mathrm{m}$.

Figure 5. The lack of spatial correlation between granule cell raphes and Bergmann glial fibers. A, A coronal section of an E12 cerebellum, with anti-vimentin staining in red and DAPI staining in blue, showing the homogeneous distribution of vimentin ${ }^{+}$glial fibers. Arrows indicate the granule cell raphes stained by DAPI. $B$, A schematic diagram of the dorsal view of granule cell raphes (in magenta) in E12 chick cerebellum. The roman numerals identify the transverse folia. The symbols $\mathrm{P} 0-\mathrm{P} 4$ denote the domains separated by the granule cell raphes. $C$, $D$, In situ hybridization with a $\operatorname{chKBP}$ probe, another marker for Bergmann glia, at E10 $(C)$ and E12 $(D)$ revealing a pattern distinct from that of the granule cell raphes shown in $B$.
(Fig. 9E,F). Other Purkinje cell markers also underwent dynamic changes during this period, such that eventually they either were expressed uniformly in the Purkinje cell layer (e.g., Bmp-7, EphA4/Cek-8) or ceased to be expressed in Purkinje cells by E15-E16 (e.g., Gli-2/4) (data not shown). These results are consistent with Feirabend's observation that the granule cell raphes disappear by E15-E16 (Feirabend, 1990). The transient nature of the granule cell raphes and of the differential gene expression in the parasagittal Purkinje cell domains suggests that E8-E15 may be indeed a critical period of parasagittal patterning in the chick cerebellum.

\section{DISCUSSION}

\section{A transient pattern for the inward migration of chick granule cells}

Patterned migratory streams of chick granule cells during the early period of inward migration had been suggested by Feirabend (1990). Using conventional histological techniques, he observed discrete arrays of tightly associated small cells connecting the EGL and IGL in the chick cerebellum between E10 and E15. He hypothesized that, during this early period, granule cell inward migration occurs predominantly in these restricted pathways, which he termed granule cell raphes. Initially unaware of Feirabend's work, we rediscovered the linear arrays of migrating granule cells when we examined the expression of several granule cell specific markers in the chick cerebellum. These markers allowed us to confirm Feirabend's conjecture that the small cells contained within the linear arrays connecting the EGL and the IGL are granule cells. We showed that granule cell raphes consisted almost exclusively of postmitotic cells, indicating that they are postmitotic granule cells undergoing inward migration rather than displaced mitotic progenitors of granule cells. Furthermore, the granule cell raphes are molecularly heterogeneous because $P a x-2$ is expressed only in the posterior portion of the granule cell raphes.

Because granule cells are generated relatively late during the course of cerebellar development (Hanaway, 1967), this patterned migration of granule cells is likely caused by a pre-established pattern of spatial cues generated by other cell type(s), such as glia and/or Purkinje cells. The critical role of neuron-glia interactions in the inward migration of granule cells (for review, see Hatten, 1993) initially led us to hypothesize that the formation of granule cell raphes was attributable to a prepattern of Bergmann glial fibers. However, we found that vimentin ${ }^{+}$glial fibers were distributed uniformly across the cerebellum and $\operatorname{chKBP}{ }^{+}$glial fibers were expressed in a pattern unrelated to the parasagittal granule cell raphes. Thus the hypothesis of a glial prepattern would require other differential modifications of glial fibers to account 

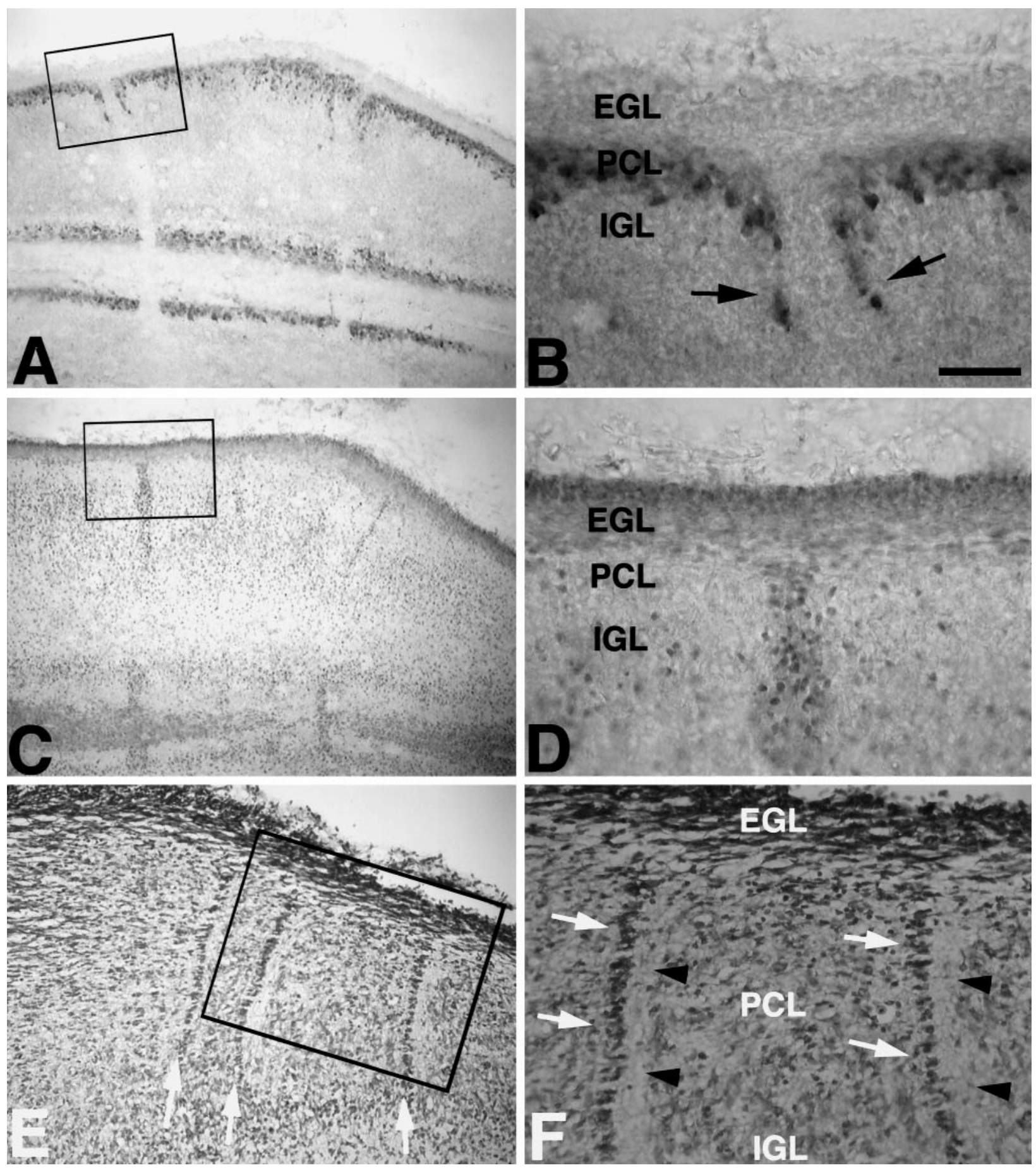

Figure 6. Complementary patterns of $\mathrm{CaBP}$ and Pax-6 expression and cresyl violet staining suggest that the continuity of the Purkinje cell layer is interrupted by the granule cell raphes. Adjacent coronal sections of an E12.5 chick cerebellum stained by anti-CaBP $(A, B)$ or anti-Pax6 $(C, D)$, both in brown, and another coronal section of an E12 chick cerebellum stained with cresyl violet $(E, F)$ are shown. Dorsal is to the top in all panels. $A-D$, The lower-power views $(A, C)$ show the positional correspondence between the Purkinje cell gaps and the granule cell raphes and that the width of the former correlated with that of the latter. The high-power views $(B, D)$ show that the Purkinje cell layer curves inwardly as it juxtaposes the granule cell raphe (arrows in $B$ ), suggesting an interruption of the Purkinje cell layer by the granule cell raphe. The rectangular frames in $A$ and $C$ indicate the high-power fields shown in $B$ and $D$, respectively. $E, F$, The relatively cell-poor zones (black arrowheads) adjacent to the granule cell raphes (white arrows), which have a high cell density similar to that of the EGL, are shown. The rectangular frame in $E$ indicates the area of higher-power view shown in $F$. EGL, External granule layer; $I G L$, internal granule layer; $P C L$, Purkinje cell layer. Scale bars: $A, C, 200 \mu \mathrm{m} ; E, 100 \mu \mathrm{m} ; B, D, F, 50 \mu \mathrm{m}$.

for the observed pattern of granule cell migration. For instance, differential expression of the putative glial receptor for astrotactin (Zheng et al., 1996) could theoretically support a nonuniform pattern of granule cell migration.
Alternatively, or additionally, there may be cellular elements other than Bergmann glia that regulate granule cell migration. This idea is partly supported by the observation that granule cell raphes almost always correspond to the gaps between coherent 

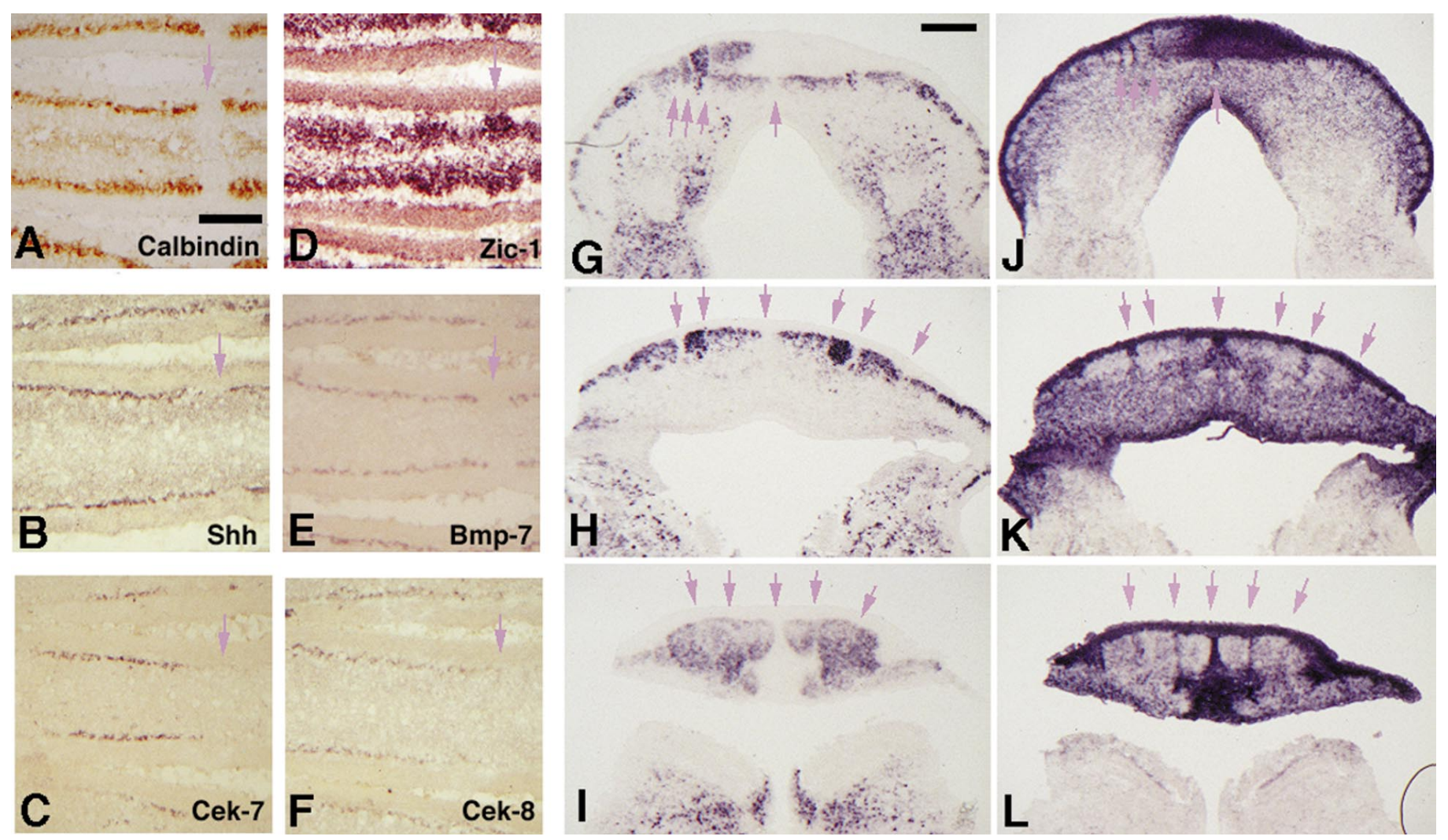

Figure 7. Identification of Purkinje cell markers in the developing chick cerebellum. $A-F$, Coronal sections of an E14 chick cerebellum, with dorsal to the top. The standard Purkinje cell marker calbindin $(A)$ was detected by anti-calbindin antibody in brown. The granule cell marker Zic-1 $(D)$ does not show the granule cell raphes as well as at the earlier stages, even though some granule cell raphes are still evident in the more posterior folia at E14 (data not shown). In situ hybridization with Shh $(B), E p h A 5 / C e k-7(C), B m p-7(E)$, and EphA4/Cek-8 (F) probes shows that they are expressed in Purkinje cells. Arrows in $A-F$ indicate the gaps devoid of any Purkinje cell marker expression. $G-L$, The domains of EphA5/Cek-7 $7^{+}$Purkinje cells that are complementary to Zic- $1^{+}$granule cell arrays. Adjacent coronal sections of E11.5 chick cerebellum were hybridized with the EphA5/Cek-7 probe $(G-I)$ or the Zic-1 probe $(J-L)$. The arrows point to the Purkinje cell gaps $(G-I)$ and the corresponding granule cell arrays $(J-L)$. It was also noted that beyond the developing cerebellar cortex, these genes were expressed in other areas of the CNS. For instance, EphA5/Cek-7 was also expressed in a subset of deep cerebellar nuclei $(G)$ and in the hindbrain $(G-I)$. Zic-1 was also expressed in the VZ of the cerebellum $(J-L)$. Additional sites of expression were also found for the other genes described here (see Discussion). Scale bars: $A-F, 200 \mu \mathrm{m} ; G-L, 400 \mu \mathrm{m}$.

clusters of Purkinje cells. Purkinje cells may, therefore, have a negative influence on the inward migration of granule cells. Recently this possibility has also been suggested by the work of Komuro and Rakic (1998). Using a mouse cerebellar slice preparation, these authors observed that granule cells temporarily slowed down during their transit of the Purkinje cell layer and that they resumed faster migration once they went into the IGL. It will be of interest to investigate the nature of the putative inhibitory effect of Purkinje cells on granule cell migration.

\section{Molecular domains of Purkinje cells and the granule cell raphes}

In characterizing the relationship between the granule cell raphes and the Purkinje cell domains during chick cerebellar development, we found that a number of genes (Bmp-7, EphA5/Cek-7, EphA4/Cek-8, En-1, En-2, Gli-2/4, and Shh) were expressed in distinct parasagittal domains of Purkinje cells. The boundaries between domains of high-expressing and low-expressing Purkinje cells for each of these genes often coincided with granule cell raphes. The correlation between the Purkinje cell gene expression patterns and the granule cell raphes illustrates how the granule cell raphes can provide a useful spatial framework for the analysis of parasagittal pattern formation of the developing chick cerebellum. Because the topographic maps of Purkinje cell pro- jections and of the various afferent inputs are also organized in parasagittal stripes, it will be important in the future to determine the relationship between the cerebellar topographic maps and the Purkinje cell domains defined by granule cell raphes.

The expression profiles of the genes we characterized are very dynamic and not solely restricted to Purkinje cells. For example, EphA5/Cek-7, EphA4/Cek-8, and Shh are also expressed in distinct subsets of cells in the deep cerebellar nuclei (see Fig. 7 for EphA5/Cek-7; our unpublished observations). En-1 and Gli-2/4 are strongly expressed in parasagittal stripes of Purkinje cells between E8 and E12 but are mainly expressed by granule cells later in development (our unpublished observations). It is thus important to note that these genes are not Purkinje cell-specific markers in the strict sense and that these genes happen to mark parasagittal domains of Purkinje cells transiently during development.

In addition to being markers for parasagittal domains, some of the genes whose expression we characterized may play a role in cerebellar development and disease. For instance, the Eph family of receptor tyrosine kinases has been implicated in the guidance of retinal axons during the formation of the retinotectal topographic map (Cheng et al., 1995; Nakamoto et al., 1996) and the establishment of the rhombomeric boundaries (Xu et al., 1995). It is thus possible that EphA5/Cek-7 and EphA4/Cek-8 may be in- 

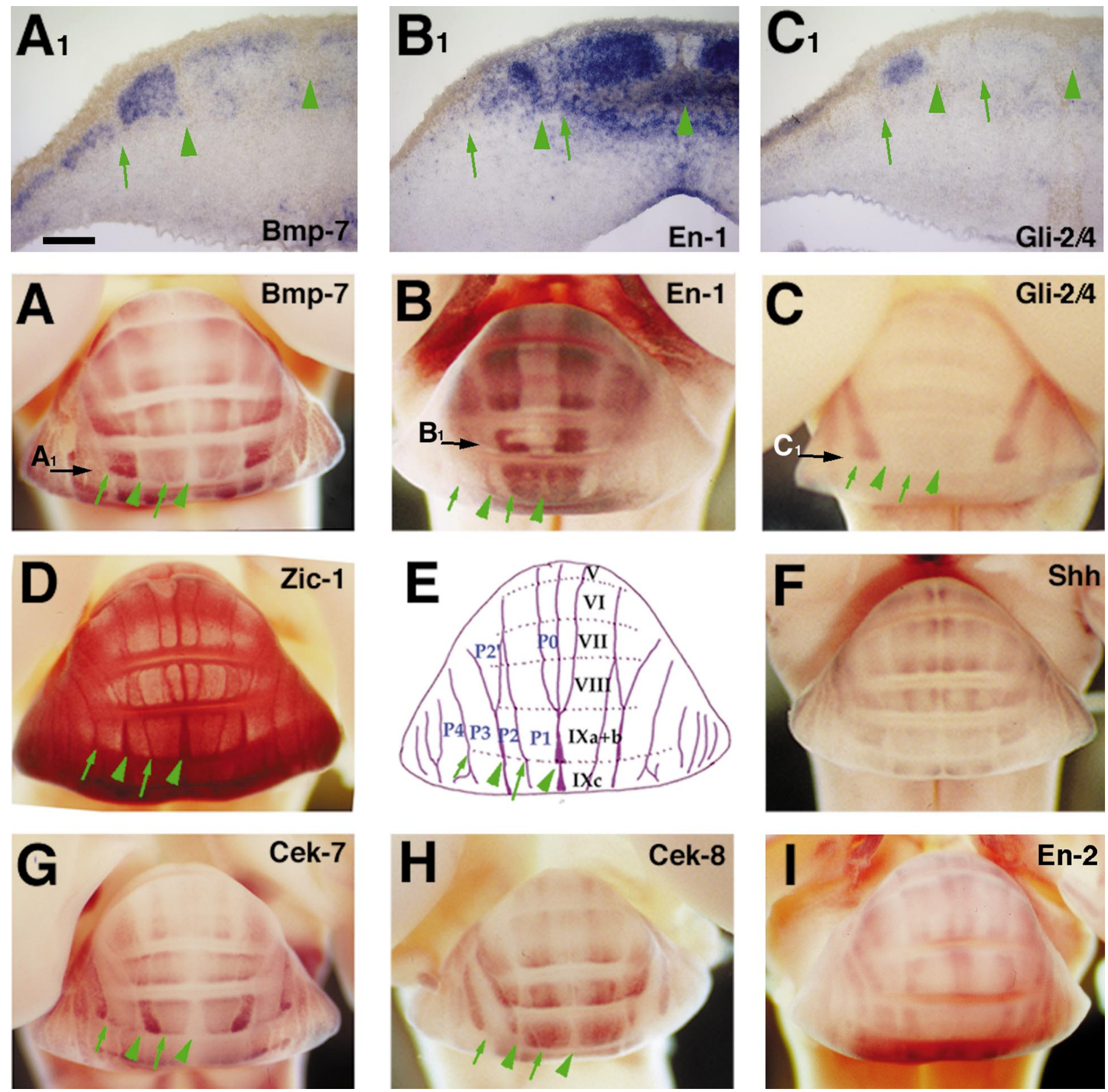

Figure 8. Parasagittal Purkinje cell domains of differential gene expression are often bordered by the granule cell arrays. A1, B1, C1, Ten millimeter coronal sections of E11.5 chick cerebellum first hybridized with Bmp-7 (A1), En-1 (B1), or Gli-2/4 (C1) (in situ signals in dark purple) and then stained with anti-Pax6 antibody (in brown). The plane of coronal section in $A 1, B 1$, and $C 1$ is indicated by the black horizontal arrow in $A, B$, and $C$, respectively. In situ hybridization of Bmp-7 (A1), En-1 (B1), or Gli-2/4 (C1) labeled the parasagittal domains of Purkinje cells, whereas anti-Pax6 antibody labeled the EGL and granule cell raphes (green arrows and arrowheads). Each of these genes was expressed at a higher level in some domains than in others, and the boundaries of gene expression tended to coincide with the granule cell raphes. $A-D, F-I$, Whole-mount in situ hybridization of E11.5 chick cerebellum with Bmp-7 (A), En-1 (B), Gli-2/4 (C), Zic-1 (D), Shh (F), EphA5/Cek-7 (G),EphA4/Cek-8 (H), and En-2 (I). Dorsal views, all with anterior at the top, are shown. $E$, The schematic representation of granule cell migratory streams (in magenta) as revealed by Zic-1 expression (E). The roman numerals identify the transverse folia. The symbols $P 0-P 4$ denote the domains separated by the granule cell raphes. Arrows and arrowheads indicate a subset of granule cell raphes defining Purkinje cell domains $P 1-P 4$ at folium IXa+b. Domains $P 1-P 4$ each had a distinct level of gene expression. See the text for a detailed description of differential gene expression in the parasagittal domains. Scale bars: $A 1, B 1, C 1,200 \mu \mathrm{m} ; A-I, 400 \mu \mathrm{m}$. 

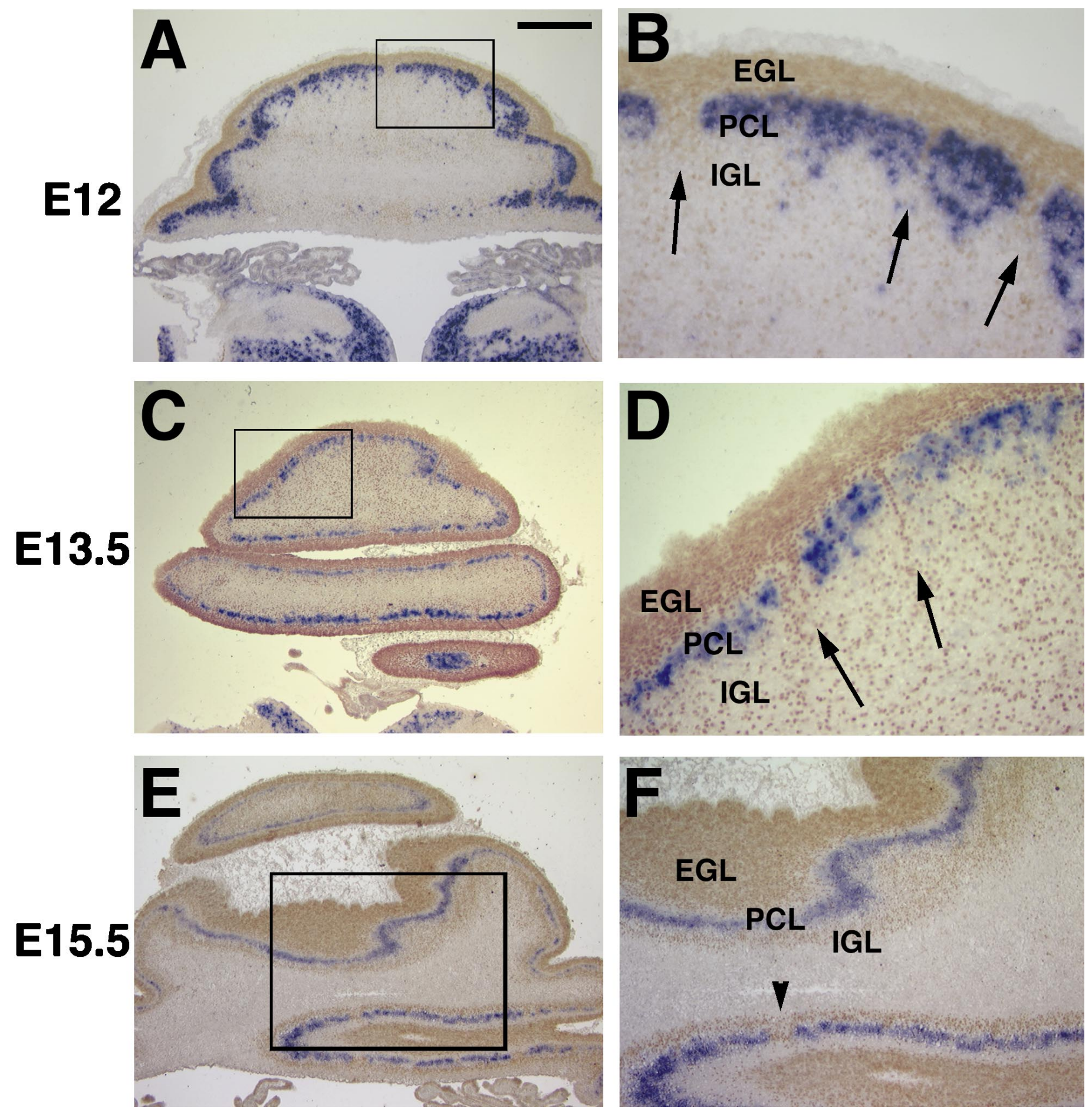

Figure 9. Granule cell raphes disappear at E15-E16. Ten millimeter coronal sections of E12 $(A, B)$, E13.5 $(C, D)$, and E15.5 $(E, F)$ chick cerebellum at the level of posterior folia (IXa-c and X). Sections were first hybridized with EphA5/Cek-7 (in situ signals in dark purple) and then stained with anti-Pax6 antibody (in brown). In situ hybridization of EphA5/Cek-7 labeled Purkinje cells, whereas anti-Pax6 antibody labeled the EGL, the IGL, and granule cell raphes (black arrows). The regular arrays of granule cell raphes connecting the EGL and IGL were very prominent at E12 $(A, B)$ and E13.5 $(C, D)$, but they became indistinct by E15.5 $(E, F)$. At E12 and E13.5, the granule cell raphes corresponded to gaps in the Purkinje cell layer $($ black arrows in $B, D$ ). However, at E15.5, there were fewer gaps in the Purkinje cell layer (black arrowhead in $F$ ). The gaps persisting to E15.5 were filled with Pax6 ${ }^{+}$ granule cells, but there was not an array of granule cells connecting the EGL and the IGL. EGL, External granule layer; IGL, internal granule layer; $P C L$, Purkinje cell layer. Scale bars: $A, C, E, 400 \mu \mathrm{m} ; B, D, F, 100 \mu \mathrm{m}$. The rectangular frames in $A, C$, and $E$ represent the areas shown in $B, D$, and $F$, respectively, at a higher magnification. 
volved in the parasagittal patterning of Purkinje cells and the topographic projections of the cerebellum. In this regard, it is noteworthy that parasagittal patterns of expression in the developing cerebellum have been described for several members of the cadherin family, which have been implicated in similar developmental processes as well (Arndt et al., 1998).

\section{Evolutionary considerations on the parasagittal patterns in the developing cerebellum - comparison of the mouse and the chick}

Mammalian and avian cerebella are very similar in terms of their gross morphology, histology, and local circuitry (for review, see Llinas and Hillman, 1969). Indeed, the early patterning events leading to the formation of the cerebellar anlage have been proposed to be nearly identical in the mouse and in the chick (for review, see Joyner, 1996). The molecular mechanisms responsible for cerebellar development, however, must diverge at some later stage to generate the species-specific features of the cerebellum. For example, the mouse cerebellum has a large pair of lateral hemispheres receiving the corticopontine afferents, whereas the analogous region of the chick cerebellum is relatively small (Brodal et al., 1950). Even among mammalian species, there are substantial variations in the relative size of the mediolateral divisions of the cerebellum (for review, see Jansen, 1969) and in the topographic maps of the afferent projections (for review, see Voogd, 1969).

Drosophila segmentation gene homologs are transiently expressed in a parasagittal pattern in both the mouse and the chick during cerebellar development (Millen et al., 1995; the present study). As the pair-rule genes and the segment-polarity genes are instrumental for the segmentation of the Drosophila embryo, the expression of vertebrate homologs in parasagittal patterns in the developing cerebellum suggested a potential role in the parasagittal patterning of the cerebellar cortex (Millen et al., 1995). A comparison of their expression patterns, however, reveals significant differences between the mouse and the chick. For example, murine En-1 is expressed in a set of three stripes (Millen et al., 1995), whereas the chick En-1 is most strongly expressed in two pairs of paramedial stripes (Fig. $8 B 1, B$ ). The murine En-2 is expressed in five stripes (Millen et al., 1995), and the chick En-2 is expressed in many more stripes (Fig. 8I). The murine Pax-2 is expressed in six parasagittal bands (Millen et al., 1995), but the chick Pax-2 is expressed in the VZ and in a subset of granule cell raphes in the posterior folia (Fig. $2 G$; our unpublished observations). Moreover, the murine $W n t-7 b$ is expressed in six parasagittal bands, whereas the chick $W n t-7 b$ is expressed only in two parasagittal stripes (our unpublished observations).

One potential objection to the above comparison is that the expression patterns might not be examined at the equivalent period of cerebellar development of each species and are thus not directly comparable. Both groups (Millen et al., 1995; present study), however, have examined the cerebellar expression of these genes extensively, and each has observed a specific window of time when these genes are expressed in parasagittal stripe patterns. The period of patterned gene expression observed in the chick cerebellum is E7-E12 and that in the mouse cerebellum is E15.5-P2 (Millen et al., 1995). Considering the general course of cerebellar histogenesis (for review, see Fujita, 1969), the time when the two hemicerebella fuse in the midline (chick at E7-E8; mouse at E15-E16) and also the period when the afferent axons start to invade the cerebellum [chick spinocerebellar axons at E8-E9 (Okado et al., 1987); chick olivocerebellar axons at E9-
E10 (Chedotal et al., 1996); mouse spinocerebellar axons at E15-E16 (Grishkat and Eisenman, 1995); and mouse olivocerebellar axons at E15 (Paradies and Eisenman, 1993)], we are led to the conclusion that the periods of the parasagittal gene expression patterns for the two species are developmentally equivalent.

It is possible that the interspecies differences in the expression patterns of the segmentation genes may underlie the different subdivisions of the cerebellum between mouse and chick. It is noteworthy in this regard that to date no equivalent anatomical structure of granule cell raphes has been reported in the mammalian cerebellum, although we found evidence of granule cell raphes in at least several avian species. Further study of the differences of cerebellar development among vertebrate species will help us better understand the evolution of this ancient part of the brain.

\section{REFERENCES}

Altman J, Bayer SA (1997) Development of the cerebellar system: in relation to its evolution, structure and functions. New York: CRC.

Arndt K, Nakagawa S, Takeichi M, Redies C (1998) Cadherin-defined segments and parasagittal cell ribbons in the developing chicken cerebellum. Mol Cell Neurosci 10:211-228.

Aruga J, Yokota N, Hashimoto M, Furuichi T, Fukuda M, Mikoshiba K (1994) A novel zinc finger protein, Zic, is involved in neurogenesis, especially in the cell lineage of cerebellar granule cells. J Neurochem 63:1880-1890.

Aruga J, Nagai T, Tokuyama T, Hayashizaki Y, Okazaki Y, Chapman VM, Mikoshiba K (1996) The mouse Zic gene family. J Biol Chem 271:1043-1047.

Borycki A-G, Mendham L, Emerson Jr CP (1998) Control of somite patterning by Sonic hedgehog and its downstream signal response genes. Development 125:777-790.

Brodal A, Kristiansen K, Jansen J (1950) Experimental demonstration of a pontine homologue in birds. J Comp Neurol 92:23-70.

Chedotal A, Pourquie O, Ezan F, San Clemente H, Sotelo C (1996) $\mathrm{BEN}$ as a presumptive target recognition molecule during the development of the olivo cerebellar system. J Neurosci 16:3296-3310.

Cheng H-J, Nakamoto M, Bergemann AD, Flanagan JG (1995) Complementary gradients in expression and binding of ELF-1 and MEK4 in development of the topographic retinotectal projection map. Cell 82:371-381.

Darnell DK, Schoenwolf GC, Ordahl CP (1992) Changes in dorsoventral but not rostrocaudal regionalization of the chick neural tube in the absence of cranial notochord, as revealed by expression of engrailed-2. Dev Dyn 193:389-396.

Feirabend HKP (1990) Development of longitudinal patterns of the cerebellum of the chicken (Gallus domesticus): a cytoarchitectural study on the genesis of cerebellar modules. Eur J Morphol 28:169-233.

Fujita S (1969) Autoradiographic studies on histogenesis of the cerebellar cortex. In: Neurobiology of cerebellar evolution and development (Llinas R, ed), pp 743-747. Chicago: AMA-ERF Inst Biomed Res.

Gao W-Q, Hatten ME (1994) Immortalizing oncogenes subvert the establishment of granule cell identity in developing cerebellum. Development 120:1059-1070.

Gregor P, Mano I, Maoz I, McKeown M, Teichberg VI (1989) Molecular structure of the chick cerebellar kainate-binding subunit of a putative glutamate receptor. Nature 342:689-692.

Grishkat HL, Eisenman LM (1995) Development of the spinocerebellar projection in the prenatal mouse. J Comp Neurol 363:93-108.

Hallonet MER, Teillet M-A, LeDouarin NM (1990) A new approach to the development of the cerebellum provided by the quail-chick marker system. Development 108:19-31.

Hanaway J (1967) Formation and differentiation of the external granular layer of the chick cerebellum. J Comp Neurol 131:1-14.

Hatten ME (1993) The role of migration in central nervous system neuronal development. Curr Opin Neurobiol 3:38-44.

Hatten ME, Heintz N (1995) Mechanisms of neural patterning and specification in the developing cerebellum. Annu Rev Neurosci 18:385-408.

Hawkes R, Mascher C (1994) The development of molecular compartmentation in the cerebellar cortex. Acta Anat 151:139-149. 
Hawkes R, Brochu G, Dore L, Gravel C, Leclerc N (1992) Zebrins: molecular markers of compartmentation in the cerebellum. In: The cerebellum revisited (Llinas R, Sotelo C, eds), pp 22-55. New York: Springer.

Jansen J (1969) On cerebellar evolution and organization, from the point of view of a morphologist. In: Neurobiology of cerebellar evolution and development (Llinas R, ed), pp 881-893. Chicago: AMA-ERF Inst Biomed Res.

Joyner AL (1996) Engrailed, Wnt and Pax genes regulate midbrainhindbrain development. Trends Genet 12:15-20.

Komuro H, Rakic P (1998) Distinct modes of neuronal migration in different domains of developing cerebellar cortex. J Neurosci 18:1478-1490.

Llinas R, Hillman DE (1969) Physiological and morphological organization of the cerebellar circuits in various vertebrates. In: Neurobiology of cerebellar evolution and development (Llinas R, ed), pp 43-73. Chicago: AMA-ERF Inst Biomed Res.

Marigo V, Johnson RL, Vortkamp A, Tabin CJ (1996) Sonic hedgehog differentially regulates expression of GLI and GLI3 during limb development. Dev Biol 180:273-283.

Millen KJ, Hui C-C, Joyner AL (1995) A role for En-2 and other murine homologues of Drosophila segment polarity genes in regulating positional information in the developing cerebellum. Development 121:3935-3945

Nakamoto M, Cheng H-J, Friedman GC, McLaughlin T, Hansen MJ, Yoon CH, O'Leary DDM, Flanagan JG (1996) Topographically specific effects of ELF-1 on retinal axons in vitro and retinal axon mapping in vivo. Cell 86:755-766.

Noramly S, Pisenti J, Abbott U, Morgan B (1996) Gene expression in limbless mutants: polarized gene expression in the absence of $S h h$ and an AER. Dev Biol 179:339-346.

Oh S-H, Johnson RL, Wu DK (1996) Differential expression of bone morphogenetic proteins in the developing vestibular and auditory sensory organs. J Neurosci 16:6463-6475.

Okado N, Yashimoto M, Furber SE (1987) Pathway formation and the terminal distribution pattern of the spinocerebellar projection in the chick embryo. Anat Embryol (Berl) 176:165-174.

Otero RA, Sotelo C, Alvarado-Mallat R-M (1993) Chick/quail chimeras with partial cerebellar grafts: an analysis of origin and migration of cerebellar cells. J Comp Neurol 333:597-615.

Paradies MA, Eisenman LM (1993) Evidence of early topographic organization in the embryonic olivocerebellar projection: a model system for the study of pattern formation processes in the central nervous system. Dev Dyn 197:125-145.

Rakic P (1971) Neuro-glia relationship during granule cell migration in developing cerebellar cortex. J Comp Neurol 141:283-312.

Ramon y Cajal S (1911) Histologie du systeme nerveus de l'homme et des vertebres. Paris: Maloine. Reprint, Histology of the nervous system (Swanson N, Swanson LW, translators). New York: Oxford UP, 1995.

Raymond JL, Lisberger SG, Mauk MD (1996) The cerebellum: a neuronal learning machine? Science 272:1126-1131.

Riddle RD, Johnson RL, Laufer E, Tabin C (1993) Sonic hedgehog mediates the polarizing activity of the ZPA. Cell 75:1401-1416.

Roeling TAP, Feirabend HKP (1988) Glial fiber pattern in the developing chicken cerebellum: vimentin and glial fibrillary acidic protein immunostaining. Glia 1:398-402.

Ryder EF, Cepko CL (1994) Migration patterns of clonally related granule cells and their progenitors in the developing chick cerebellum. Neuron 12:1011-1029.

Sajjadi FG, Pasquale EB (1993) Five novel avian Eph-related tyrosine kinases are differentially expressed. Oncogene 8:1807-1813.

Somogyi P, Eshhar N, Teichberg VI, Roberts D (1990) Subcellular localization of a putative kainate receptor in Bergmann glial cells using a monoclonal antibody in the chick and fish cerebellar cortex. Neuroscience 35:9-30.

Stoykova A, Gruss P (1994) Roles of Pax genes in developing and adult brain as suggested by expression patterns. J Neurosci 14:1395-1412.

Voogd J (1969) The importance of fiber connections in the comparative anatomy of the mammalian cerebellum. In: Neurobiology of cerebellar evolution and development (Llinas R, ed), pp 493-514. Chicago: AMAERF Inst Biomed Res.

Wassef M, Angaut P, Arsenio-Nunes L, Bourat F, Sotelo C (1992) Purkinje cell heterogeneity: its role in organizing the topography of the cerebellar cortex connections. In: The cerebellum revisited (Llinas R, Sotelo C, eds), pp 5-21. New York: Springer.

Xu Q, Alldus G, Holde N, Wilkinson DG (1995) Expression of truncated Sek-1 receptor tyrosine kinase disrupts the segmental restriction of gene expression in the Xenopus and zebrafish hindbrain. Development 121:4005-4016.

Zhang L, Goldman JE (1996) Generation of cerebellar interneurons from dividing progenitors in white matter. Neuron 16:47-54.

Zheng C, Heintz N, Hatten ME (1996) CNS gene encoding astrotactin, which supports neural migration along glial fibers. Science 272:417-419. 